\title{
Absorption and distribution of cadmium of three maize hybrids in three environments
}

\author{
Jorge Retamal-Salgado ${ }^{1}$, Ivan Matus², Ingrid Walter ${ }^{3}$ and Juan Hirzel2*
}

${ }^{1}$ Universidad de Concepción, Facultad de Agronomía, Avenida Vicente Méndez 595, Chillán, Chile. ${ }^{2}$ Instituto de Investigaciones Agropecuarias, INIA Quilamapu, Avenida Vicente Méndez 515, Chillán, Chile. ${ }^{3}$ Instituto Nacional de Investigación y Tecnología Agraria y Alimentaria (INIA), Apdo. Correos 8111, 28080 Madrid, España. *Corresponding author: jhirzel@inia.cl

\begin{abstract}
Anthropogenic soil contamination with heavy metals has received much attention in recent years, especially cadmium $(\mathrm{Cd})$, which is a very toxic element for human health and is exposure is mainly through contaminated food. Maize (Zea mays L.) is one of the most important cereals in the human diet that is characterized as species whose cultivars differ in $\mathrm{Cd}$ accumulation. Therefore, identifying and selecting low Cd-accumulating genetic material will contribute to reducing its ingestion. Among the agricultural crops that are important for $\mathrm{Cd}$ in the human diet is maize. Cadmium contents in three maize cultivars were grown under different environments conditions in Chile where soils were enriched with increasing Cd rates, were evaluated. Grain yield, Cd concentration in different plant tissues, and soil post-harvest, were evaluated. Results showed that grain yield was not affected by soil $\mathrm{Cd}$; however, plant tissues generally exhibited differences in $\mathrm{Cd}$ concentration associated with the environment, La Serena showed the highest grain $\mathrm{Cd}$ accumulation $\left(30 \mu \mathrm{g} \mathrm{kg}^{-1} ; \mathrm{P}<0.05\right)$. In addition, among cultivars, Pioneer showed the highest grain Cd concentration $\left(19.5 \mu \mathrm{g} \mathrm{kg}^{-1} ; \mathrm{P}<0.05\right)$. Grain Cd concentration of the three maize cultivars were within the range cited in the bibliography as not toxic.
\end{abstract}

Keywords: Cadmium, maize, Chilean soils, Zea mays 


\section{Introduction}

There is a growing concern regarding food security because of environmental pollution. Anthropogenic soil contamination by heavy metals has been produced mainly by industry or agriculture, e.g., foundries, metalliferous mine waste, pesticides, fertilizers, and municipal organic waste (Siebers et al., 2014). Cadmium is one of the heavy metals that is usually found in low concentrations in the soil (Rothbaum et al 1986; Quezada-Hinojosa et al., 2015; Seshadri et al., 2015). It is toxic for living organisms and carcinogenic for human beings (Liu et al., 2015; Seshadri et al., 2015). Although it is not an essential plant nutrient, $\mathrm{Cd}$ can be absorbed in larger quantities than other elements, such as cobalt and nickel, with no adverse effects on growth (Eshghi and Ranjbar, 2014; Seshadri et al., 2015). Cadmium also interacts with the metabolism of three essential metals: $\mathrm{Ca}, \mathrm{Zn}$, and Fe, generating their low intake by means of substitution and increase of competitive mobility with other elements (Goyer, 1997; Mora et al., 2016). The human body can absorb Cd through food, especially leaves and grains, water, or air: it accumulates and persists for a long time causing health problems (Liu et al., 2015). The World Health Organization (WHO) has considered a daily $\mathrm{Cd}$ intake of $0.83 \mu \mathrm{g} \mathrm{kg}^{-1}$ body weight or $58.1 \mu \mathrm{g} \mathrm{Cd}$ per person as toxic for human beings (WHO, 2010). Cadmium accumulates in the liver and kidneys and has a long biological half-life of 17 to $30 \mathrm{y}$ in humans. Its toxicity involves two organ systems, kidney and skeleton, and is largely the result of interactions between $\mathrm{Cd}$ and essential metals, particularly generating low Ca intake (Goyer, 1997). The European Union has identified maximum Cd concentrations of some agricultural products as 50, 100, 200, and $200 \mu \mathrm{g} \mathrm{kg}^{-1}$ for fruit, root vegetables, wheat, and lettuce, respectively (Berg and Litcht, 2002).
Crop and cultivar species differ widely in their ability to absorb, accumulate, and tolerate Cd (Yang et al., 2014). Among the agricultural crops that are important for $\mathrm{Cd}$ in the human diet are, durum wheat (Triticum turgidum L. var. durum), maize (Zea mays L.), wheat (Triticum aestivum L.), oat (Avena sativa L.), barley (Hordeum vulgare L.), rice (Oryza sativa L.), and pea (Pisum sativum L.); these have exhibited Cd concentrations over the limits permitted for human health (Fahad et al., 2015; Quezada-Hinojosa et al., 2015). The amount of soil Cd mainly depends on its origin, and physical and chemical properties, such as clay, acidity, salinity, Zn, and organic matter (OM) content. Phosphorus and $\mathrm{N}$ fertilization, organic amendment applications, exposure to contamination sources, crop rotation, and management practices are the main sources of increased soil Cd content (Siebers et al., 2014). As for the soil Cd concentration considered as a risk, various authors point out that the value ranges from 0.8 to $1.0 \mathrm{mg} \mathrm{Cd} \mathrm{kg}^{-1}$ (Quezada-Hinojosa et al., 2015). A similar value is indicated by Segura et al. (2006) for soils in Chile.

Another factor affecting both $\mathrm{Cd}$ availability and uptake by plants is root exudation of organic acids, such as citrate and malate (Adeniji et al., 2010; Seshadri et al., 2015). White lupin (Lupinus albus L.) is defined as a species that exudes elevated levels of organic acids that can increase soil $\mathrm{Cd}$ availability, but restricts $\mathrm{Cd}$ transport from the roots to the stems and grains (Tejo et al., 2016).

Given that the world population and its demand for food is increasing over time (FAO, 2015), a larger area is needed for agricultural use. Some of the available soils could have total $\mathrm{Cd}$ concentrations close to or greater than the $1 \mathrm{mg} \mathrm{kg}^{-1}$ critical level; this will require species and cultivars exhibiting lower $\mathrm{Cd}$ 
accumulation and translocation. To contribute in providing maize cultivars that exhibit low $\mathrm{Cd}$ accumulation in both grain and straw, the objective of the present study was to evaluate the response of three maize cultivars grown with increasing $\mathrm{Cd}$ rates in three different agroclimatic zones of Chile.

\section{Materials and Methods}

2.1. Climatic and soil characteristics of each environment

The environments in which the field experiments were conducted, located in three contrasting agro- climatic zones: i) La Serena ( $\left.30^{\circ} 3^{\prime} \mathrm{S}, 71^{\circ} 14^{\prime} \mathrm{W}\right)$, colluvial-alluvial soil (Typic Haplocambids; USDA, 2014), arid climate with maritime influence, and 40 $\mathrm{mm}$ precipitation concentrated in winter; ii) Los Tilos (333' ' S, $70^{\circ} 37^{\prime}$ W), alluvial soil (Haploxeroll; USDA, 2014), semi-arid and temperate Mediterranean climate with hot and dry summer, cold winter, and $163 \mathrm{~mm}$ precipitation; and iii) Chillán (36 $31^{\circ}$, S, 71 ${ }^{\circ} 54^{\prime}$ W), volcanic soil (Melanoxerand; USDA, 2014), temperate Mediterranean climate with hot and dry summer, cold and humid winter, and 672 $\mathrm{mm}$ precipitation concentrated in winter and beginning of spring (Table 1) (Red Agrometeorológica de INIA, 2013).

Table 1. Climatic characteristics of each environment during the 2013 season.

\begin{tabular}{|c|c|c|c|c|c|c|c|c|c|}
\hline & \multicolumn{3}{|c|}{ La Serena } & \multicolumn{3}{|c|}{ Los Tilos } & \multicolumn{3}{|c|}{ Chillán } \\
\hline & $\mathrm{Tm}$ & $\mathrm{pp}$ & Ev & $\mathrm{Tm}$ & $\mathrm{Pp}$ & Ev & $\mathrm{Tm}$ & $\mathrm{pp}$ & Ev \\
\hline January & 19.5 & 0.0 & 60.0 & 20.7 & 0.0 & 138.1 & 19.9 & 1.2 & 134. \\
\hline February & 19.8 & 0.0 & 47.9 & 18.8 & 0.0 & 105.8 & 18.5 & 19.3 & 101.9 \\
\hline March & 16.6 & 0.0 & 103.6 & 17.0 & 0.0 & 88.4 & 15.1 & 4.1 & 78.5 \\
\hline April & 14.1 & 0.0 & 62.5 & 13.4 & 0.0 & 36.6 & 12.4 & 6.1 & 40.6 \\
\hline May & 12.3 & 61.1 & 37.1 & 11.4 & 0.0 & 20.9 & 9.4 & 183.0 & 21.5 \\
\hline June & 10.4 & 8.2 & 22.9 & 7.3 & 39.1 & 16.5 & 7.3 & 123.7 & 12.4 \\
\hline July & 9.9 & 5.7 & 28.7 & 8.2 & 4.5 & 20.3 & 7.1 & 110.1 & 16.1 \\
\hline August & 11.3 & 0.5 & 47.2 & 9.3 & 35.8 & 34.6 & 8.2 & 128.0 & 20.8 \\
\hline September & 12.9 & 0.3 & 71.1 & 11.3 & 5.7 & 45.6 & 9.7 & 49.9 & 52.6 \\
\hline October & 13.5 & 0.2 & 102.0 & 14.3 & 0.1 & 74.1 & 12.7 & 35.7 & 86.4 \\
\hline November & 15.6 & 7.8 & 78.7 & 16.4 & 0.0 & 125.9 & 15.2 & 11.0 & 123.1 \\
\hline December & 17.8 & 0.0 & 142.6 & 19.2 & 0.0 & 146.9 & 19.1 & 0.0 & 156.7 \\
\hline Total accumulation & -- & 83.8 & 804.3 & -- & 85.2 & 853.7 & -- & 672.1 & 845.0 \\
\hline
\end{tabular}

Tm, mean temperature $\left({ }^{\circ} \mathrm{C}\right)$; pp, precipitation $(\mathrm{mm})$; Ev, evaporation $(\mathrm{mm})$ 
The physico-chemical properties of each soil analyzed at the start of the experiment are shown in Table 2. The samples were collected at two depths $(0-0.2$ and $0.2-0.4 \mathrm{~m}$ ) and the physico-chemical analyses were performed according to the methodology indicated by Sadzawka et al. (2006). Soil pH was measured in a 1:2.5 (soil/water) ratio. Organic matter was estimated by the Walkley-Black wet digestion method. Soil available $\mathrm{N}\left(\mathrm{NO}_{3}-\mathrm{N}\right.$ and $\left.\mathrm{NH}_{4}-\mathrm{N}\right)$ was previously extracted with $1 \mathrm{M} \mathrm{KCl}$ and determined by colorimetry in a Skalar Auto Analyzer (segmented flow spectrophotometer). Available P was extracted with $0.5 \mathrm{M}$ $\mathrm{NaHCO}_{3}$ (Olsen-P) and determined by the ascorbic acid-molybdate method. Exchangeable $\mathrm{Ca}, \mathrm{Mg}, \mathrm{K}$, and $\mathrm{Na}$ were extracted with $1 \mathrm{M}$ ammonium acetate and measured using flame emission spectrometry ( $\mathrm{K}$ and $\mathrm{Na}$ ) and atomic absorption ( $\mathrm{Ca}$ and $\mathrm{Mg}$ ) spectrometry (AAS). The soil exchangeable Al concentration was determined by extraction with $1 \mathrm{M} \mathrm{KCl}$ and AAS. Concentrations of DTPA extractable Fe, Mn, Zn, and $\mathrm{Cu}$ were determined (Lindsay and Norvell, 1978) and by AAS. Boron was determined by colorimetry after acid digestion. Soil and plant $\mathrm{Cd}$ was quantified by electrothermal atomic absorption spectrophotometry (graphite furnace technique) with Thermo Elemental Solaar M5 equipment coupled to a Model GF95 graphite furnace. Samples were digested in a microwave oven (MARS-Xpress, CEM Corporation, Matthews, North Carolina, USA) before the spectrophotometry reading. For each soil sample, $0.5 \mathrm{~g}$ was weighed and $10 \mathrm{~mL} \mathrm{HNO}_{3}$ (nitric acid 65\%, Suprapur Nitric Acid, Merck Millipore, Darmstadt, Germany) were added, whereas $1 \mathrm{~g}$ maize DM in digestion tubes was weighed and $10 \mathrm{~mL}$ Suprapur $\mathrm{HNO}_{3}+1 \mathrm{~mL} \mathrm{30 \%} \mathrm{H}_{2} \mathrm{O}_{2}$ were added. Quality control for the analysis was based on certified reference material (ISE 979 for soil and IPE 981 for plant tissue), comparing samples between laboratories, internal control samples, and duplicates of the analyses (Tejo et al., 2016).
Table 2. Soil physical and chemical properties $(0-0.2$ and 0.2 - $0.4 \mathrm{~m}$ depths).

\begin{tabular}{|c|c|c|c|c|c|c|}
\hline \multirow[t]{3}{*}{ Parameters } & \multicolumn{6}{|c|}{ Environments and depths (m) } \\
\hline & \multicolumn{2}{|c|}{ La Serena } & \multicolumn{2}{|c|}{ Los Tilos } & \multicolumn{2}{|c|}{ Chillán } \\
\hline & $0-0.2$ & $0.2-0.4$ & $0-0.2$ & $0.2-0.4$ & $0-0.2$ & $0.2-0.4$ \\
\hline Clay $(\%)$ & 20.2 & 20.3 & 21.5 & 27.3 & 20.7 & 15.9 \\
\hline Silt (\%) & 30.2 & 31.2 & 50.0 & 49.3 & 43.6 & 45.4 \\
\hline Sand $(\%)$ & 49.6 & 48.5 & 28.5 & 23.4 & 35.7 & 38.7 \\
\hline Bulk density $\left(\mathrm{g} \mathrm{cm}^{-3}\right)$ & 1.76 & 1.80 & 1.20 & 1.24 & 1.00 & 1.05 \\
\hline pH (soil:water 1:5) & 6.94 & 6.87 & 8.25 & 8.19 & 5.74 & 5.76 \\
\hline Organic matter $\left(\mathrm{g} \mathrm{kg}^{-1}\right)$ & 11.6 & 11.3 & 19.6 & 21.7 & 63.0 & 56.2 \\
\hline $\mathrm{EC}\left(\mathrm{dS} \mathrm{m} \mathrm{m}^{-1}\right)$ & 0.15 & 0.23 & 0.11 & 0.15 & 0.11 & 0.07 \\
\hline Available $\mathrm{N}\left(\mathrm{mg} \mathrm{kg}^{-1}\right)$ & 18.0 & 20.0 & 11.0 & 14.0 & 40.0 & 38.0 \\
\hline Olsen-P (mg kg-1) & 51.3 & 44.9 & 3.9 & 5.1 & 35.2 & 25.3 \\
\hline Exchangeable $\mathrm{K}\left(\mathrm{cmol}_{\mathrm{c}} \mathrm{kg}^{-1}\right)$ & 0.85 & 0.67 & 0.35 & 0.41 & 0.65 & 0.39 \\
\hline Exchangeable $\mathrm{Ca}\left(\mathrm{cmol}_{\mathrm{c}} \mathrm{kg}^{-1}\right)$ & 8.12 & 8.22 & 20.70 & 19.66 & 6.74 & 5.89 \\
\hline Exchangeable $\mathrm{Mg}\left(\mathrm{cmol}_{\mathrm{c}} \mathrm{kg}^{-1}\right)$ & 2.41 & 2.61 & 0.92 & 0.86 & 0.95 & 0.72 \\
\hline Exchangeable $\mathrm{Na}\left(\mathrm{cmol}_{\mathrm{c}} \mathrm{kg}^{-1}\right)$ & 0.59 & 0.69 & 0.49 & 0.40 & 0.16 & 0.19 \\
\hline Exchangeable $\mathrm{Al}\left(\mathrm{cmol}_{\mathrm{c}} \mathrm{kg}^{-1}\right)$ & 0.05 & 0.05 & 0.04 & 0.04 & 0.21 & 0.10 \\
\hline Available $\mathrm{Fe}\left(\mathrm{mg} \mathrm{kg}^{-1}\right)$ & 21.5 & 20.8 & 16.7 & 17.0 & 59.8 & 46.5 \\
\hline Available $\mathrm{Mn}\left(\mathrm{mg} \mathrm{kg}^{-1}\right)$ & 36.3 & 34.3 & 11.8 & 11.5 & 9.8 & 5.4 \\
\hline Available $\mathrm{Zn}\left(\mathrm{mg} \mathrm{kg}^{-1}\right)$ & 4.5 & 4.4 & 1.1 & 1.2 & 0.7 & 0.6 \\
\hline Available $\mathrm{Cu}\left(\mathrm{mg} \mathrm{kg}^{-1}\right)$ & 9.2 & 9.3 & 8.9 & 8.8 & 1.4 & 1.2 \\
\hline Available B ( $\left.\mathrm{mg} \mathrm{kg}^{-1}\right)$ & 2.3 & 2.4 & 0.8 & 0.8 & 0.5 & 0.4 \\
\hline Available S (mg kg-1) & 40.8 & 64.9 & 11.9 & 13.5 & 14.2 & 15.4 \\
\hline Total Cd $\left(\mathrm{mg} \mathrm{kg}^{-1}\right)$ & 1.33 & 1.49 & 0.52 & 0.51 & 0.21 & 0.18 \\
\hline
\end{tabular}

EC, electrical conductivity

\subsection{Cadmium rates and maize cultivars}

Cadmium was applied as $\mathrm{CdCl}_{2}(61.3 \% \mathrm{Cd})$ at rates of 0 , 1 , and $2 \mathrm{mg} \mathrm{kg}^{-1}$ adjusted for a $0-0.2 \mathrm{~m}$ soil depth and considered the bulk density of each soil (Table 2). The equivalent amount of $\mathrm{Cd}$ applied at the 1 and $2 \mathrm{mg} \mathrm{kg}^{-1}$ $\mathrm{CdCl}_{2}$ rates in each environment was: i) La Serena 2157.76 and $4315.52 \mathrm{~g} \mathrm{ha}^{-1}$, respectively; ii) Los Tilos 1593.8 and $3187.6 \mathrm{~g} \mathrm{ha}^{-1}$, respectively, and iii) Chillán 1226.0 and $2452.0 \mathrm{~g} \mathrm{ha}^{-1}$, respectively.

The maize cultivars used in the study were Syngenta NK 703 in La Serena and Los Tilos and Syngenta NK Exp in Chillán; Pioneer P 32 D12 in La Serena and Los Tilos and Pioneer P 37 W 05 in Chillán; Dekalb DK 627 in La Serena and Los Tilos and Dekalb DK 469 in Chillán. These cultivars were 
selected because the Syngenta, Pioneer, and Dekalb genotypes exhibit different genetic characteristics, and different responses would be expected.

\subsection{Agronomic management of the experiment}

Agronomic management practices were standardized for all the environments using Chilean norms for this crop. The N, P, and K fertilization rates were 360, 120 , and $120 \mathrm{~kg} \mathrm{ha}^{-1}$, respectively, and fertilizer sources were urea, triple superphosphate, and potassium chloride. Nitrogen was applied $30 \%$ and $70 \%$ at sowing and the sixth leaf stage, respectively. Both $\mathrm{P}$ and $\mathrm{K}$ were applied $100 \%$ at sowing.

Each experimental unit consisted of five 3-m long rows with $0.6 \mathrm{~m}$ row spacing $\left(9 \mathrm{~m}^{2}\right)$. The cultivated area at each environment was $223 \mathrm{~m}^{2}$ considering three $\mathrm{Cd}$ rates, three maize cultivars, and three replicates for each experimental unit. Experiments were sown on 8, 17, and 24 October in La Serena, Los Tilos, and Chillán, respectively. The sowing rate was 8 seeds $\mathrm{m}-1$ at the three environments. The seedbed was prepared by ploughing at a depth of $0.3 \mathrm{~m}$ followed by the surface cultivator and two crosswise harrowings at $45^{\circ}$.

Six or seven irrigation events were applied after sowing up to the milk stage of kernel development to complement precipitation accumulated between October and December 2013 (8.0, 0.1, $46.7 \mathrm{~mm}$ in La Serena, Los Tilos, and Chillán, respectively, Table 1). From 50 to $60 \mathrm{~mm}$ were applied during each irrigation event; this maintained adequate soil moisture to ensure good crop development. The pre-emergent herbicide was a mixture of atrazine and s-metolachlor (Primagran Gold $660 \mathrm{SC}$ ) that was applied at $6.0 \mathrm{~L}$ $\mathrm{ha}^{-1}$ at the post-emergence stage to control dicotyledonous weeds. The chlorpyrifos insecticide (Pirinex $48 \mathrm{EC}$ ) was applied at $5.0 \mathrm{~L} \mathrm{ha}^{-1}$ before sowing to control larvae in the soil. The incidence of diseases and insects was very low and leaf fungicides and insecticides were not used.

Plots were harvested on 22, 24, and 29 April 2014 in La Serena, Los Tilos, and Chillán, respectively.

\subsection{Grain yield, and Cd analysis in soil and plant} tissue

When grains reached $15 \%$ moisture content, the crop was harvested and GY determined. Samples of plants with roots were collected from $1.0 \mathrm{~m} 2$ in each experimental plot; these were then separated into grain, straw, and root. The separated samples were washed with distilled water and oven-dried at $70{ }^{\circ} \mathrm{C}$ for $72 \mathrm{~h}$. At the end of the experiment, 10 soil samples were collected from each plot at the $0-0.2$ and $0.2-0.4 \mathrm{~m}$ depths; these were air-dried and passed through a 2 $\mathrm{mm}$ sieve to determine total $\mathrm{Cd}$.

\subsection{Statistical analysis}

A split-split-plot experimental design was used where main plot was environment (3), split plots were $\mathrm{Cd}$ rates (3), and split-split-plots were maize cultivars (3); each treatment was triplicated.

The results were analyzed by ANOVA. A mean separation test was then performed (Tukey, $\mathrm{P}=0.05$ ) using the SAS general model procedure (SAS Institute, 1989).

\section{Results}

Grain yield fluctuated between 5.5 and $15.5 \mathrm{Mg} \mathrm{ha}^{-1}$; the highest value was obtained in La Serena followed by Chillán and both had higher GY than Los Tilos. Grain yield was affected only by environment $(\mathrm{P}<$ 0.05 , Figure 1) and by the interaction between the $\mathrm{Cd}$ rate and maize cultivars $(\mathrm{P}<0.05$, Table 3$)$, while the $\mathrm{Cd}$ rate, cultivars, and resulting interactions with environments did not affect this parameter (Table 3). 
Figure 1. Maize grain yield at three environments as a mean of different cultivars and $\mathrm{Cd}$ rates.

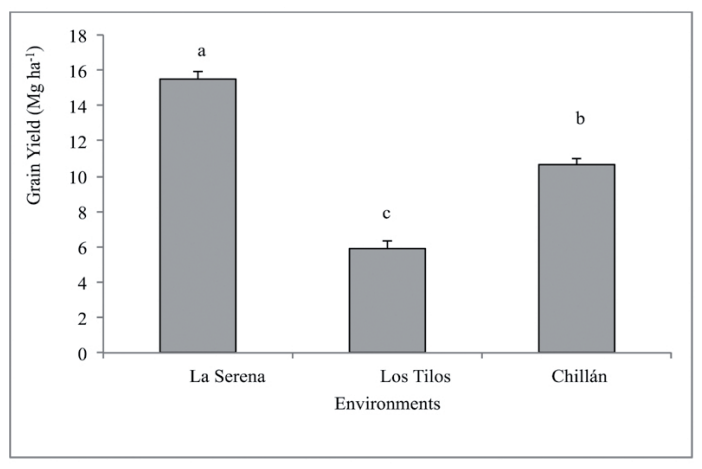

Different letters over the bars indicate significant differences according to Tukey's test $(p<0.05)$.

Table 3. Significance levels of evaluated parameters for experiments conducted with three maize hybrids fertilized with three $\mathrm{CdCl}_{2}$ rates at three environments.

\begin{tabular}{|c|c|c|c|c|c|c|c|}
\hline Parameter & $\mathrm{Li}$ & Rii & Ciii & $\mathrm{L} \times \mathrm{R}$ & $\mathrm{L} \times \mathrm{C}$ & $\mathrm{R} \times \mathrm{C}$ & $\mathrm{L} \times \mathrm{R} \times \mathrm{C}$ \\
\hline Grain yield & $* *$ & NS & NS & NS & NS & * & NS \\
\hline Straw DM production & $* *$ & NS & NS & NS & $* *$ & NS & NS \\
\hline Root DM production & $* *$ & NS & $* *$ & NS & $* *$ & NS & NS \\
\hline Grain Cd content & $* *$ & $* *$ & NS & $*$ & $* *$ & NS & NS \\
\hline Straw Cd content & $* *$ & $* *$ & NS & $* *$ & NS & $* *$ & NS \\
\hline Root $\mathrm{Cd}$ content & $* *$ & $* *$ & NS & $* *$ & NS & NS & NS \\
\hline Soil Cd from $0-0.2 \mathrm{~m}$ & $* *$ & $* *$ & NS & $* *$ & $*$ & NS & NS \\
\hline Soil Cd from $0.2-0.4 \mathrm{~m}$ & $* *$ & ** & NS & * & NS & NS & NS \\
\hline
\end{tabular}

Li, environments (3) La Serena, Los Tilos, and Chillán; Rii, Cadmium rates (3) 0, 1, and $2 \mathrm{mg} \mathrm{kg}^{-1}$; Ciii, maize hybrids (3) Syngenta, Pioneer, and Dekalb.

NS, nonsignificant, ${ }^{*} p<0.05,{ }^{*} p p<0.01$.
Grain Cd content was affected by the environment, $\mathrm{Cd}$ rate, and the Environment $\times$ Cd Rate and Environment $\times$ Cultivar interactions (Table 3). For environment or environment, the highest mean value for grain $\mathrm{Cd}$ content was obtained in La Serena $\left(30.0 \mu \mathrm{g} \mathrm{kg}^{-1}\right)(\mathrm{P}<0.05)$, which was greater than in Los Tilos $(12.7 \mu \mathrm{g}$ $\left.\mathrm{kg}^{-1}\right)$ and Chillán $\left(12.0 \mu \mathrm{g} \mathrm{kg}^{-1}\right)$, which were not different $(\mathrm{P}>0.05)$ (Figure 2a). When comparing $\mathrm{Cd}$ rates (mean values of environments and cultivars), the highest grain $\mathrm{Cd}$ content was obtained with $2 \mathrm{mg} \mathrm{kg}^{-1} \mathrm{CdCl}_{2}\left(21.2 \mu \mathrm{g} \mathrm{kg}^{-1}\right)$ and $1 \mathrm{mg} \mathrm{kg}^{-1} \mathrm{CdCl}_{2}\left(15.5 \mu \mathrm{g} \mathrm{kg}^{-1}\right)$ rates; there were nonsignificant differences one from the other $(\mathrm{P}>0.05)$ and both were higher than the control where $\mathrm{Cd}$ was not applied $\left(4.3 \mu \mathrm{g} \mathrm{kg}^{-1}\right)$ $(\mathrm{P}<0.05)$ (Figure $2 \mathrm{~b}$ ). Regarding the cultivars (mean values of environments and $\mathrm{Cd}$ rates), it was observed that grain $\mathrm{Cd}$ contents in Pioneer (14.6 $\left.\mu \mathrm{g} \mathrm{kg}^{-1}\right)$, Dekalb (13.1 $\left.\mu \mathrm{g} \mathrm{kg}^{-1}\right)$, and Syngenta $\left(13.0 \mu \mathrm{g} \mathrm{kg}^{-1}\right)$ were non-significantly different one from the other $(p>0.05)$ (Figure $2 c)$. The interactions that affected grain $\mathrm{Cd}$ content variability had a greater effect in La Serena (Figure 2). Straw Cd content was affected by environment, $\mathrm{Cd}$ rate, and the Environment $\times$ $\mathrm{Cd}$ Rate and $\mathrm{Cd}$ Rate $\times$ Cultivar interactions (Table 3). For agroclimatic zones (mean values of cultivars and $\mathrm{Cd}$ rates), the highest straw $\mathrm{Cd}$ content was obtained in Los Tilos (3356.4 $\mu \mathrm{g}$ $\left.\mathrm{kg}^{-1}\right)$ followed by Chillán $\left(2037.5 \mu \mathrm{g} \mathrm{kg}^{-1}\right)$ and there were non-significant differences between the two $(p>0.05)$; however, both were significantly higher than La Serena $\left(1283.7 \mu \mathrm{g} \mathrm{kg}^{-1}\right)(p$ $<0.05$ ) (Figure 2a). 
Figure 2. Cadmium content in the maize plant for a) different environments, b) cadmium rates, and c) hybrids.
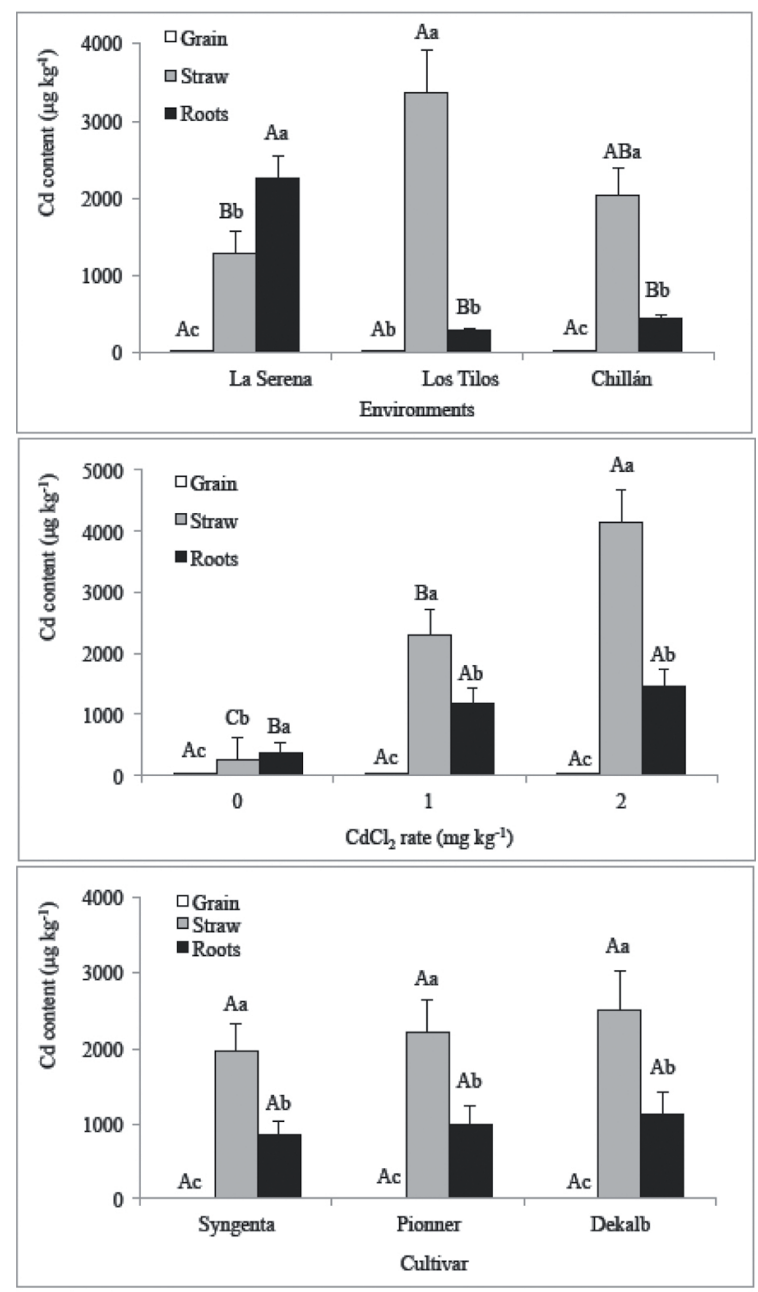

For each figure, different uppercase letters over the bars indicate significant differences in the same plant structure (grain, straw, roots) compared for a) environments, b) cadmium rates, and c) maize hybrids according to Tukey's test $(p<0.05)$.

For each figure, different lower-case letters over the bars indicate significant differences in the same plant structure (grain, straw, roots) for each a) environment, b) cadmium rates, and c) maize hybrid according to Tukey's test $(p<0.05)$.
For the Cd rates (mean values of the environment and cultivars), the highest straw $\mathrm{Cd}$ content was obtained with $2 \mathrm{mg} \mathrm{kg}^{-1} \mathrm{CdCl}_{2}$ rate that was significantly higher than $1 \mathrm{mg} \mathrm{kg}^{-1} \mathrm{CdCl}_{2}$ rate $(p<0.05)$; both were significantly higher than the control with no $\mathrm{Cd}(p<0.05)$. For the 2, 1 , and $0 \mathrm{mg} \mathrm{kg}^{-1} \mathrm{CdCl}_{2}$ rates, values were $3395.6,1883.2$, and $203.8 \mu \mathrm{g} \mathrm{kg}^{-1}$, respectively (Figure 2b). For cultivars (mean values of environments and $\mathrm{Cd}$ rates), values of straw $\mathrm{Cd}$ content sorted in descending order were Dekalb (2017.4 $\mu \mathrm{g} \mathrm{kg}^{-1}$ ), Pioneer (1947.2 $\mu \mathrm{g} \mathrm{kg}^{-1}$ ), and Syngenta $\left(1618.0 \mu \mathrm{g} \mathrm{kg}^{-1}\right)$ and these were nonsignificantly different one from the other $(\mathrm{p}>$ 0.05 ) (Figure 2c). The interactions in straw $\mathrm{Cd}$ content indicated that the highest variability associated with using different $\mathrm{Cd}$ rates was $5895.8 \mu \mathrm{g} \mathrm{kg}^{-1}$ of Cd in stem residue in Los Tilos (data not shown). Root Cd content was affected by environment, $\mathrm{Cd}$ rate, and the Environment $\times$ Cd Rate interaction (Table 3 ). When considering the environment (mean values of cultivars and $\mathrm{Cd}$ rates), the highest root $\mathrm{Cd}$ content was found in La Serena $\left(2252.8 \mu \mathrm{g} \mathrm{kg}^{-1}\right)$ and it was significantly different from the other two environments $(\mathrm{p}<0.05)$; Chillán $\left(439.8 \mu \mathrm{g} \mathrm{kg}^{-1}\right)$ and Los Tilos $\left(283.8 \mu \mathrm{g} \mathrm{kg}^{-1}\right)$ were non-significantly different one from the other $(p>0.05)$ (Figure 2a). For $\mathrm{Cd}$ rates (mean values of environments and cultivars), the highest root $\mathrm{Cd}$ contents were obtained with the 2 and $1 \mathrm{mg} \mathrm{kg}^{-1} \mathrm{CdCl}_{2}$ rates; there were non-significant differences between the two $(p>0.05)$ with values of 1215.6 and $945.3 \mu \mathrm{g} \mathrm{kg}^{-1}$, respectively, which significantly surpassed $(p<0.05)$ the control $\left(273.0 \mu \mathrm{g} \mathrm{kg}^{-1}\right.$, Figure $2 b$ ). Regarding the cultivars (mean values of environments and $\mathrm{Cd}$ rates), root $\mathrm{Cd}$ concentrations were $907.8 \mu \mathrm{g} \mathrm{kg}^{-1}$ in Dekalb, $816.9 \mu \mathrm{g}$ $\mathrm{kg}^{-1}$ in Pioneer, and $709.3 \mu \mathrm{g} \mathrm{kg}^{-1}$ in Syngenta 
and there was non-significant difference among them $(p>0.05)$ (Figure 2c). The interactions in the root $\mathrm{Cd}$ concentration exhibited higher variability associated with the environment where the mean concentration found in La Serena was 5.1 and 7.9 times higher than in Chillán and Los Tilos, respectively (Figures 2a, 2b).

For differences in the tissues of a single plant, usually from the same agroclimatic zone, the highest $\mathrm{Cd}$ concentration was in the straw, with the exception of La Serena where the root had the highest Cd concentration; grain and root $\mathrm{Cd}$ concentrations were non significantly different $(\mathrm{P}>0.05)$ among environments (Figure 2a). For the same Cd rate, the effect was similar to the abovementioned observations (Figure 2b). Finally, the highest concentration for any one cultivar was also in the straw, but the values were non-significantly different one from the other (Figure 2c).

Total soil $\mathrm{Cd}$ at harvest in both the first and second soil layers $(0-0.2$ and $0.2-0.4 \mathrm{~m})$ was affected by the environment, $\mathrm{Cd}$ rate, and Environment $\times \mathrm{Cd}$ Rate interaction; only the first layer was affected by the Environment $\times$ Cultivar interaction (Table 3). When comparing environments for the first soil layer (0 - $0.2 \mathrm{~m}$ ), the highest total $\mathrm{Cd}$ concentrations were obtained in Los Tilos and La Serena and there were significant differences between the two $(\mathrm{P}>0.05)$ with values of 1.97 and $1.95 \mathrm{mg} \mathrm{kg}^{-1}$, respectively; these values were also significantly higher $(p<0.05)$ than in Chillán where total $\mathrm{Cd}$ concentration was $0.81 \mathrm{mg} \mathrm{kg}^{-1}$ (Table 3 and Figure 3a). Different Cd rates (Table 3 and Figure 3b) showed that total soil $\mathrm{Cd}$ concentration was significantly equal for the two applied $\mathrm{Cd}$ rates (2 and $\left.1 \mathrm{mg} \mathrm{kg}^{-1} \mathrm{CdCl}_{2}\right)(\mathrm{P}>0.05)$ whose values were 2.13 and $1.48 \mathrm{mg} \mathrm{kg}^{-1}$, respectively, while the control value $\left(0.5 \mathrm{mg} \mathrm{kg}^{-1} \mathrm{Cd}\right)$ was only significantly different at the highest $\mathrm{Cd}$ rate $(\mathrm{P}$ $<0.05$ ) (Figure 3b).
Figure 3. Soil total cadmium content in two soil depths at maize crop harvest for different a) environments, b) cadmium rates, and c) hybrids.
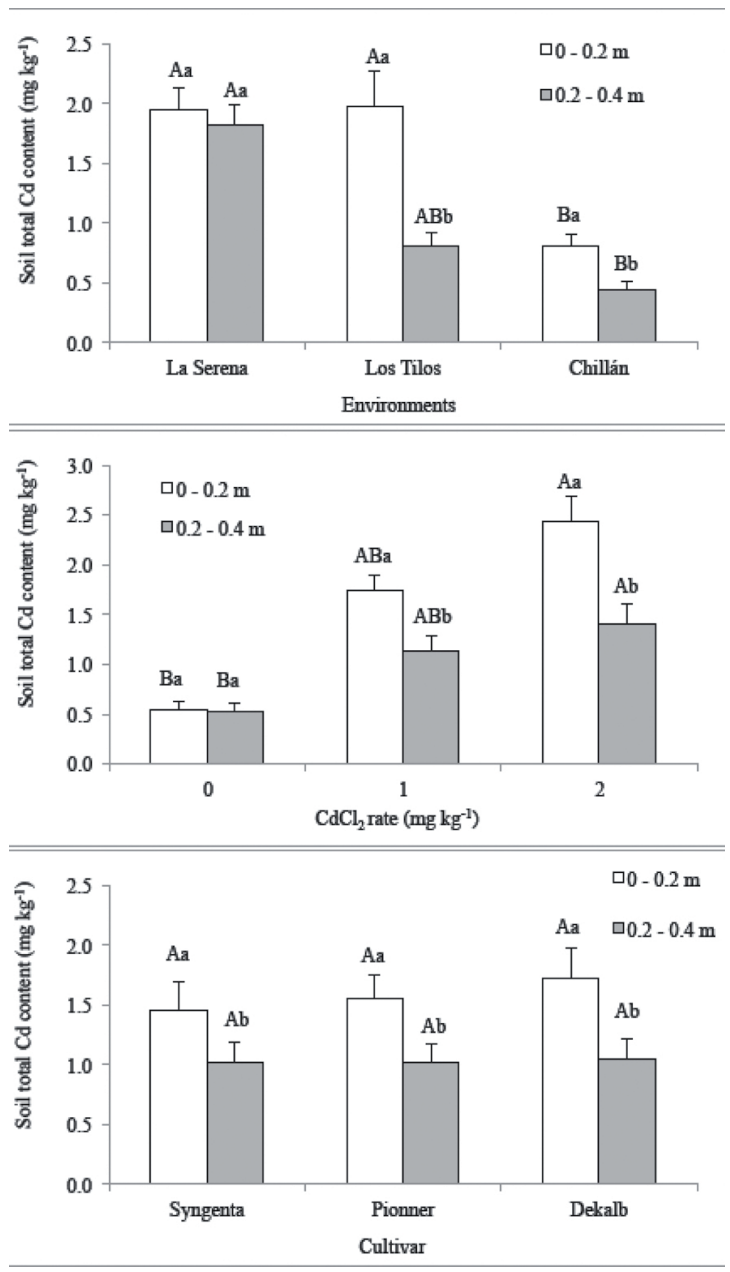

For each figure, different uppercase letters over the bars indicate significant differences at the same soil depth compared for a) environments, b) cadmium rates, and c) maize hybrids according to Tukey's test $(p<0.05)$.

For each figure, different lower-case letters over the bars indicate significant differences between soil depths for each a) environment, b) cadmium rates, and c) maize hybrid according to Tukey's test $(p<0.05)$. 
When comparing environments for the second soil layer $(0.2-0.4 \mathrm{~m})$, the highest total $\mathrm{Cd}$ concentrations were obtained in La Serena $\left(1.82 \mathrm{mg} \mathrm{kg}^{-1}\right)$ and Los Tilos $\left(0.81 \mathrm{mg} \mathrm{kg}^{-1}\right)$; there were non-significant differences between the two $(p>0.05)$. On the other hand, the value in Chillán $\left(0.45 \mathrm{mg} \mathrm{kg}^{-1}\right)$ was quite lower than the other environments, but only showed significant differences with La Serena $(p<0.05)$ (Figure 3a). Mean values obtained by applying the different $\mathrm{Cd}$ rates, 0, 1, and $2 \mathrm{mg} \mathrm{kg}^{-1} \mathrm{CdCl}_{2}$ were 0.47, 0.97, and $1.27 \mathrm{mg} \mathrm{kg}^{-1}$, respectively. The highest total $\mathrm{Cd}$ concentration in the second soil layer occurred, as expected, when applying the $2 \mathrm{mg} \mathrm{kg}^{-1} \mathrm{CdCl}_{2}$ rate, which only surpassed the control value $(p>0.05)$; the value obtained with the $1 \mathrm{mg} \mathrm{kg}^{-1}$ rate showed nonsignificant differences when compared to either the control or the highest applied $\mathrm{CdCl}_{2}$ rate $(p>0.05)$ (Figure $3 b$ ).

The concentration in the second soil depth showed non-significant differences $(\mathrm{P}>0.05)$ among cultivars (Figure 3c); this is similar to the result obtained in the first soil layer $(0-0.20 \mathrm{~m})$.

\section{Discussion}

Maize grain yields (GY) obtained in La Serena and Chillán (Figure 1) were similar to GY found by other authors for this species under adequate agronomic management conditions. However, GY obtained in Los Tilos was lower than the value recorded by these authors and lower than expected in the study area (Liu et al., 2013; Shah et al., 2016). The limitations of GY for this environment are mainly due to the lack of heat accumulation during the development period (Table 1); this coincides with findings described by Liu et al. (2013) who observed a significant correlation between GY and mean temperature and accumulation of degree-days.

Maize grain $\mathrm{Cd}$ concentration (Figures 2a, 2b, 2c) showed values within the range cited by Yang et al.
(2014); this is the mean value of $\mathrm{Cd}$ found in the present study, $0.015 \mathrm{mg} \mathrm{kg}^{-1}$ (mean of 27 values that consider three environments, three $\mathrm{Cd}$ rates, and three cultivars). Yang et al. (2014) obtained a mean grain $\mathrm{Cd}$ concentration of $0.03 \mathrm{mg} \mathrm{kg}^{-1}$ (mean of nine $\mathrm{Cd}$ rates). Grain $\mathrm{Cd}$ concentration values for all the treatments in the present study did not surpass the allowable limits of $0.2 \mathrm{mg} \mathrm{kg}^{-1}$ pointed out by several authors (Arduini et al., 2014). Maize grain Cd concentration values, obtained by averaging cultivars and environments, were lower in all cases than those pointed out by Yang et al. (2014) for different maize cultivars (Figures 2a, 2b, 2c). Several authors have pointed out that maize grain $\mathrm{Cd}$ concentration is below the detection limit of $0.002 \mathrm{mg} \mathrm{kg}^{-1}$ (Wahsha et al., 2014). Therefore, the low grain $\mathrm{Cd}$ accumulation could be due to several factors: 1) uptake and translocation limitations generated in the root (Adeniji et al., 2010; Yang et al., 2014), which suggests that maize plants appear to have more efficient defence mechanisms than other crops to deal with Cd toxicity, including its accumulation in the root (Adeniji et al., 2010); 2) soil available $\mathrm{Zn}$ concentration since $\mathrm{Zn}$ is an antagonist to plant Cd uptake (Tanwir et al., 2015); and 3) low $\mathrm{Cd}$ concentration could be attributable to the high agronomic efficiency of nutrient use (kg DM produced per kg of applied nutrient) obtained in this experiment (data not shown) compared with other studies cited in the literature, which implied an overall nutrient dilution effect (Fahad et al., 2015). However, applying increasing $\mathrm{Cd}$ rates produced an increase of more than $100 \%$ in maize grain $\mathrm{Cd}$ accumulation when compared with the control with no applied Cd (Arduini et al., 2014; Yang et al., 2014). Although differences among environments were found in the controls, this fact could be related to the initial total soil Cd concentration (Table 2); this has been reported by numerous authors (Degryse et al., 2009; Yang et al., 2014). On the other hand, differences in grain $\mathrm{Cd}$ concentration 
detected among environments could be due to higher mineral use efficiency (Arduini et al., 2014). When comparing cultivars, grain $\mathrm{Cd}$ concentration in the controls, in addition to being low, was similar in the different evaluated cultivars (Syngenta, Pioneer and Dekalb); this contributes in selecting genetic material with low $\mathrm{Cd}$ accumulation for the agroclimatic conditions in Chile.

Regarding the straw Cd concentration, Wahsha et al. (2014) cite values of 0.021 and $0.058 \mathrm{mg} \mathrm{kg}^{-1}$ as the mean $\mathrm{Cd}$ concentration in stems and leaves, respectively. Mean straw $\mathrm{Cd}$ values obtained in the present study in La Serena, Los Tilos, and Chillán were higher than those reported by Wahsha et al. (2014), which was probably due to the initial soil $\mathrm{Cd}$ concentration as indicated by Putwatana et al. (2015). Maize straw $\mathrm{Cd}$ concentration for the mean of cultivars was also higher than those mentioned by Wahsha et al. (2014); however, Cd was applied in two of the three treatments in the present study, which could have affected the abovementioned mean concentration values (Putwatana et al., 2015; Yang et al., 2014).

The highest root $\mathrm{Cd}$ concentration (mean of environments) was obtained in La Serena (Figure 2a), which can be associated with the initial soil Cd concentration (Table 2) (Degryse et al., 2009). Results at the other two environments (Los Tilos and Chillán) did not coincide with those found by other authors, who indicate that roots always exhibit higher $\mathrm{Cd}$ concentrations than other parts of the plant (Wahsha et al., 2014; Putwatana et al., 2015; Tanwir et al., 2015); this suggests that $\mathrm{Cd}$ distribution in the plant could be related to the cultivar (Yang et al., 2014). Likewise, root $\mathrm{Cd}$ concentration in Los Tilos would have been expected to be higher than in Chillán (Figure 2a) because it was associated with higher soil $\mathrm{Cd}$ concentration (Table 2). However, soluble Cd compounds could have been immobilized by increases in $\mathrm{pH}$ (Degryse et al., 2009), especially in values higher than
8.2 such as those found in Los Tilos (Table 2). It has also been observed that roots can exude compounds that increase environment $\mathrm{pH}$, decrease availability, and restrict Cd uptake (Tanwir et al., 2015). On the contrary, another factor that would explain low $\mathrm{Cd}$ accumulation in Chillán for grain, stem, and root could be due to greater competition between the $\mathrm{H}^{+}$and $\mathrm{Cd}^{+2}$ cations in the uptake sites on the root surface (Larsson and Asp, 2013). A directly proportional response was found between the applied $\mathrm{Cd}$ rate and root $\mathrm{Cd}$ concentration (Figure 2b); results were similar to those reported by Liu et al. (2013), and values corresponded to an increase equivalent to 3.5 and 4.5 times compared with the control when applying 1 and $2 \mathrm{mg} \mathrm{kg}^{-1}$ $\mathrm{CdCl}_{2}$, respectively. In general, the residue had higher $\mathrm{Cd}$ concentration compared to grain and root (Figure $2 \mathrm{a}, 2 \mathrm{~b}$, and $2 \mathrm{c}$ ). In this regard, similar results were observed in other crops as higher $\mathrm{Cd}$ concentrations in stems of lettuce (Lactuca sativa L.) and amaranth (Amaranthus caudatus L.) by Egwu and Agbenin (2013) and wheat (Triticum aestivum L.) by Siebers et al. (2014). Also, these results were similar to those of Liang et al. (2005), he found higher Cd concentration in residue than in the rest of maize plants. This higher $\mathrm{Cd}$ concentration in residue would indicate a higher Cd transference rate to the aerial part influenced by a decrease of sap flow, which would generate an increase of $\mathrm{Cd}$ concentration in xylem by exposure of this crop to high concentrations of this metal, as stated by Liang et al. (2005). These higher concentrations in aerial parts expose animals and human beings to this heavy metal. So, these results would help us to discriminate these cultivars for animal feeding decreasing the transference risk of this heavy metal to human being. For cultivars, the lowest root $\mathrm{Cd}$ concentration was obtained in Syngenta; Pioneer surpassed Syngenta and Dekalb by $15 \%$ and $11 \%$, respectively (Figure 2c); however, there was nonsignificant difference among cultivars $(p<0.05)$. 
Total Cd concentrations in the first soil layer ( 0 - 0.2 m) of the present study were similar to those cited by some authors for soils with different agricultural use (Rothbaum et al., 1986; Quezada-Hinojosa et al., 2015) (Figures 3a, 3b, 3c), and also similar to those cited by Segura et al. (2006) for different soils in Chile. Values were lower at $1 \mathrm{mg} \mathrm{kg}^{-1}$, which is identified as the critical soil Cd level (Quezada-Hinojosa et al., 2015). When comparing environments, higher total Cd concentration was found in La Serena (Figure $3 \mathrm{a}$ ), which could be associated with its initial $\mathrm{Cd}$ content (Table 2) and available $\mathrm{Zn}$ concentration (Degryse et al., 2009; Fahad et al., 2015). Even though initial soil total Cd concentration in La Serena was higher than in Los Tilos and Chillán (Table 2), this order was not maintained when concentrations were analyzed at the end of crop growth (Figure 3a). This situation could be explained by the formation of complexes between the metal and OM (Degryse et al., 2009); taking into account that Chillán had a higher $\mathrm{OM}$ concentration than the other environments, $\mathrm{Cd}$ availability is reduced (Table 2). When comparing Los Tilos and La Serena, the former would also be influenced by higher OM content than La Serena, which would reduce Cd availability (Degryse et al., 2009). As expected, the $\mathrm{Cd}$ rate used was directly proportional to soil concentration (Figure 3b), which coincides with findings reported in the literature (Arduini et al., 2014; Fahad et al., 2015); both applied $\mathrm{CdCl}_{2}$ rates were higher than the critical threshold of this element in soils $\left(1 \mathrm{mg} \mathrm{kg}^{-1}\right)$. Regarding the maize cultivars under study, no effect was recorded on soil total $\mathrm{Cd}$ concentration (Figure 3c).

In general, the second soil layer $(0.2-0.4 \mathrm{~m})$ exhibited a similar effect as the one found in the first soil layer when comparing environments and $\mathrm{Cd}$ rates. However, concentrations and the magnitude of the differences were lower (Figures 3a, 3b). This effect could be attributable to the characteristics of this element in the soil, which is mainly located at the surface (Rothbaum et al., 1986). When comparing the environments, the $\mathrm{Cd}$ concentration was higher in Los Tilos than Chillán (Figure 3a), unlike the result in the first soil layer. This could be due to the higher salinity found in Los Tilos (Table 2).

\section{Conclusions}

Results show that the presence of Cd in the soil (baseline and applied) did not affect maize yield. In turn, the $\mathrm{Cd}$ concentration in both maize grain and straw was affected by crop environment and applied soil $\mathrm{Cd}$. The $\mathrm{Cd}$ concentration in the roots was affected by the environment and also by applied soil $\mathrm{Cd}$. In roots, $\mathrm{Cd}$ concentration was affected by environment and also by soil $\mathrm{Cd}$ application. The cultivars evaluated in the present study showed no differences in $\mathrm{Cd}$ concentration in none of the analyzed tissues, which does not allow the selection of a cultivar with a lower $\mathrm{Cd}$ accumulation for contaminated environments or at risk of being contaminated with this metal. The highest grain Cd concentration was found in La Serena environment (30 $\left.\mu \mathrm{g} \mathrm{kg}^{-1} ; \mathrm{P}<0.05\right)$ and in Pioneer cultivar $\left(19.5 \mu \mathrm{g} \mathrm{kg}^{-1} ; \mathrm{P}<0.05\right)$, but in no case corresponded to the value considered as the limit $(0.2 \mathrm{mg}$ $\mathrm{kg}^{-1}$ ). Finally, once the maize was harvested, soil total $\mathrm{Cd}$ concentration depended on the environment and the $\mathrm{Cd}$ rate used, and higher accumulation occurred in the first soil layer.

\section{Acknowledgements}

This study was funded by Chile FONDECYT Project 1120992. 


\section{References}

Adeniji, B.A., Budimir-Hussey, M.T., Macfie, S.M. 2010. Production of organic acids and adsorption of $\mathrm{Cd}$ on roots of durum wheat (Triticum turgidum L. var. durum). Acta Physiologiae Plantarum. 32, 1063-1072.

Arduini, I., Masoni, A., Mariotti, M., Pampana, S., Ercoli, L. 2014. Cadmium uptake and translocation in durum wheat varieties differing in grain-Cd accumulation. Plant Soil Environment. 60, 43-49.

Berg, T., Licht, D. 2002. International legislation on trace elements as contaminants in food: A review. Food Additives and Contaminants. 10, 916-927.

Degryse, F., Smolders, E., Parker, D. R. 2009. Partitioning of metals $(\mathrm{Cd}, \mathrm{Co}, \mathrm{Cu}, \mathrm{Ni}, \mathrm{Pb}, \mathrm{Zn})$ in soils: concepts, methodologies, prediction and applications - a review. European Journal of Soil Science. 60, 590-612.

Egwu, G., Agbenin, J. 2013. Field assessment of cadmium, lead and zinc contamination of soils and leaf vegetables under urban and peri-urban agriculture in northern Nigeria. Archives of Agronomy and Soil Science. 59, 875-887.

Eshghi, S., and Ranjbar, R. 2015. Vegetative growth, yield and leaf mineral composition in strawberry (Fragaria $\times$ ananassa Duch. cv. Pajaro) as influenced using nickel sulfate and urea sprays. Journal of Plant Nutrition. 36, 1336-1345.

Fahad, S., Hussain, S., Saud, S., Hassan, S., Darakhshan, Y., Chen, N., Deng, F., Khan, Ch., Wu, W., Wu, F., Shah, B., Ullah, M., Yousaf, S., Ali, S., Huang, J. 2015. Grain cadmium and zinc concentrations in maize influenced by genotypic variations and zinc fertilization. Clean Soil Air Water. 43, 1433-1440.

Goyer, R.A. 1997. Toxic and essential metal interactions. Annual Review of Nutrition. 17, 37-50.
Larsson, J. E., Asp, H. 2013. Effects of pH and nitrogen on cadmium uptake in potato. Biologia Plantarum. 57, 788-792.

Liang, Y., Wong, J., Wei, L. 2005. Silicon-mediated enhancement of cadmium tolerance in maize (Zea mays L.) grown in cadmium contaminated soil. Chemosphere. 58, 475-483.

Liu, Y., Hou, P., Xie, R., Li, S., Zhang, H., Ming, B., Ma, D., Liang, S. 2013. Spatial Adaptabilities of Spring Maize to Variation of Climatic Conditions. Crop Science. 53, 1693-1703.

Liu, Y., Xiao T., Baveye, P.C., Zhu, J., Ning, Z., Li, H. 2015. Potential health risk in areas with high naturally-occurring cadmium background in southwestern China. Ecotoxicology and Environmental Safety. 112, 122-131.

Lindsay, W.L., Norvell, W.A. 1978. Development of a DTPA soil test for zinc, iron, manganese, and copper. Soil Science Society of America Journal. 42, 421-428.

Mora, M.L., Durán, P., Acuña, J., Cartes, P., Demanet, R., Gianfreda, L. 2015. Improving selenium status in plant nutrition and quality. Journal of soil science and plant nutrition. 15(2), 486-503.

FAO. 2015. Agricultura mundial: hacia los años 2015/2030. [Online] Organización de las Naciones Unidas para la Agricultura y la Alimentación (FAO), Roma, Italia. Available at: http://www.fao.org.

Quezada-Hinojosa, R., Föllmi, K. B., Gillet, F., Matera, V. 2015. Cadmium accumulation in six common plant species associated with soils containing high geogenic cadmium concentrations at Le Gurnigel, Swiss Jura Mountains. Catena. 124, 85-96.

Red Agrometeorológica de INIA. 2013. Agromet: red agrometeorológica del INIA. Available at: http:// agromet.inia.cl/estaciones.php\#estaciones.

Rothbaum, H.P., Goguel, R.L., Johnston, A.E., Mattingly, G.E. 1986. Cadmium accumulation in soils 
from long continued applications of superphosphate. Journal Soil Science. 37, 99-107.

Sadzawka, A., Carrasco, M.A., Grez, R., Mora, M., Flores, H., Neaman, A. 2006. Métodos de análisis recomendados para los suelos de Chile. Serie Actas INIA No34. 164 p. Instituto de Investigaciones Agropecuarias (INIA), Santiago, Chile.

SAS Institute. 1989. Usage and Reference. Version 6. 501 p. SAS. Institute Inc., Cary, North Carolina, USA.

Segura, R., Arancibia, V., Zúñiga, M.C., Pastén, P. 2006. Distribution of copper, zinc, lead and cadmium concentrations in stream sediments from the Mapocho River in Santiago, Chile. Journal of Geochemical Exploration. 91, 71-80.

Seshadri, B., Bolan, N.S., Naidu, R. 2015. Rhizosphere-induced heavy metal(loid) transformation in relation to bioavailability and remediation. Journal of soil science and plant nutrition. 15(2), 524-548.

Siebers, N., Godlinski, F., Leinweber, P. 2014. Bone char as phosphorus fertilizer involved in cadmium immobilization in lettuce, wheat, and potato cropping. Journal Plant Nutrition and Soil Science. 177, 75-83.

Shah, G.M., Shah, G.A., Groot, J.C.J., Raza, M.A.S., Shahid, N., Latinga, E.A. 2016. Maize nitrogen recovery and dry matter production as affected by application of solid cattle manure subjected to various storage conditions. Journal of Soil Science and Plant Nutrition. 16 (3), 591-603.
Tanwir, K., Akram, M.S., Masood, S., Chaudhary, H.J., Lindberg, S., Javed, M.T. 2015. Cadmiuminduced rhizospheric $\mathrm{pH}$ dynamics modulated nutrient acquisition and physiological attributes of maize (Zea mays L.) Environmental Science and Pollution Research. 22, 9193-9203.

Trejo, N., Matus, I., del Pozo, A., Walter I., Hirzel, J. 2016. Cadmium phytoextraction capacity of white lupine (Lupinus albus L.) and narrow-leafed lupine (Lupinus angustifolius L.) in three contrasting agroclimatic conditions of Chile. Chilean Journal of Agricultural Research. 76(2), 228-235.

USDA. 2014. Keys to soil taxonomy. 12nd ed. USDA-Natural Resources Conservation Service, Washington, DC., USA, 360 p.

WHO. 2010. Exposure to cadmium: A major public health concern. Public Health and Environment, World Health Organization (WHO), Geneva, Switzerland. p. 3-6. Available at: http://www.who. int/ipcs/features/cadmium.pdf).

Wahsha, M., Fontana, S., Nadimi-Goki, M., Bini, C. 2014. Potentially toxic elements in food crops (Triticum aestivum L., Zea mays L.) grown on contaminated soils. Journal of Geochemical Exploration. 147, 189-199.

Yang, Y., Nan, Z., Zhao, Z. 2014. Bioaccumulation and translocation of cadmium in wheat (Triticum aestivum L.) and maize (Zea mays L.) from the polluted oasis soil of Northwestern China. Chemical Speciation and Bioavailability. 26, 43-51. 